УдК 351.746.1

\author{
Б. П. Ганьба, О. Б. Ганъба
}

\title{
ФУНКЦІї ЮРИДИЧНОї ВІДПОВІДАЛЬНОСТІ Й ОСОБЛИВОСТІ ЇХ ПРОЯВУ У СФЕРІ ОХОРОНИ ТА ЗАХИСТУ ДЕРЖАВНОГО КОРДОНУ УКРАЇНИ
}

Постановка проблеми. В умовах реформації правових систем суспільств перехідного типу значно активізуються наукові дослідження проблем динамічних сторін функціонуючого, «живого» права. Дослідження функцій різноманітних правових інститутів у цьому процесі посідає провідне місце.

Пропонований нами аналіз функцій юридичної відповідальності, особливостей їх прояву та реалізації, насамперед у вузьких, спеціальних правоохоронних сферах життєдіяльності держави, якою є і сфера охорони та захисту державного кордону України, дасть змогу глибше проникнути в зміст, сутність і призначення такої юридичної відповідальності, окреслити iï соціальну роль і специфіку. Адже саме у функціях юридичної відповідальності проявляються іiі призначення, мета, завдання, соціальна цінність та інші характеристики як самостійного правового явища.

Аналіз останніх досліджень і публікацій. Функції юридичної відповідальності донедавна не були самостійним предметом монографічного або дисертаційного дослідження, а розглядалися лише в контексті загальних проблем юридичної відповідальності. Окремі аспекти зазначеного явища у своїх наукових працях зачіпали такі вітчизняні та зарубіжні вчені, як I. Аземша, С. Алексєєв, С. Бобровник, В. Варкалло, С. Братусь, Є. Білозьоров, Є. Ковальський, М. Калашник, В. Копейчиков, П. Рабінович, О. Скакун та ін.

Однак вони лише підтверджували факт існування таких функцій, виділяли їх види, інколи певною мірою розкривали зміст. При цьому науковці глибоко не переймалися детальним аналізом та особливостями прояву функцій юридичної відповідальності, тим паче у спеціальних сферах правоохоронної діяльності держави.

Тому метою нашого дослідження є з'ясування окремих теоретичних проблем функцій юридичної відповідальності, а також особливостей їх прояву у сфері охорони та захисту державного кордону України. 
Зазначена мета окреслює й коло завдань, які підлягають розв'язанню в ході дослідження.

Завдання поданого матеріалу з обраної проблеми:

- узагальнення та аналіз наукових поглядів щодо трактування поняття, сутності, змісту та видів функцій юридичної відповідальності;

- характеристика структурних елементів функцій юридичної відповідальності військовослужбовців у сфері охорони та захисту державного кордону України;

- висвітлення особливостей їх прояву та реалізації у сфері охорони та захисту державного кордону України;

- формулювання авторського визначення функцій юридичної відповідальності з урахуванням специфіки досліджуваної сфери тощо.

Виклад основного матеріалу дослідження. На початку дослідження функцій юридичної відповідальності окремі вчені взагалі заперечували факт їх існування, мотивуючи це тим, що функції мають лише засоби юридичного примусу, а не юридична відповідальність [1, с. 96; 2, с. 268]. Однак така позиція не була підтримана вченим світом. На сьогодні науковці-юристи у своїй більшості визначають функції юридичної відповідальності як головні напрями юридичного впливу на особу та суспільство, що характеризують iii сутність і призначення в суспільстві тощо [3, с. 386; 4, с. 340].

Так, С. Алексєєв, І. Галаган, Д. Липинський, В. Хоменко та інші науковці трактують функції юридичної відповідальності як основні напрями впливу на суспільні відносини, певні ії прояви та призначення, як засоби впливу на свідомість відповідних суб'єктів права [5, с. 78].

При цьому більшість дослідників наголошують на тому, що у функціях юридичної відповідальності реалізується конкретний прояв функцій права в цілому [6, с. 96].

Окремі науковці (О. Зелена, М. Трофимова та ін.) концентрують увагу і на такій проблемі, як структура функцій юридичної відповідальності, яка охоплює суб'єктів, об’єктів, засоби та способи їі здійснення, фактичні та формальні підстави приведення в дію юридичної відповідальності та наслідки їі впливу [7, с. 90-96; 8, с. 4-6].

Наше дослідження зазначена проблема цікавить тому, що окремі елементи структури функцій юридичної відповідальності мають свої особливості прояву у сфері охорони та захисту державного кордону України.

Так, суб'єктами юридичної відповідальності є не тільки спеціальні суб'єкти - військовослужбовці Держприкордонслужби та правоохоронних органів, до обов'язків яких входить забезпечення охорони та захисту державного кордону України і які скоїли правопорушення, а й суб'єкти, які мають повноваження реалізації функцій юридичної відповідальності (безпосередні начальники, представники військової прокуратури тощо).

Об'єктами функцій юридичної відповідальності є як поведінка окремих військовослужбовців, так і їхніх підрозділів як колективних суб'єктів (їх воля, колективна й індивідуальна свідомість тощо). 
Метою функцій юридичної відповідальності в досліджуваній сфері $€$ насамперед проблема запобігання правопорушенням із боку військовослужбовців, забезпечення їхньої правомірної поведінки, особливо під час несення ними служби. Важливою метою є також підвищення їхньої правосвідомості та правової культури, притягнення до відповідальності та покарання винних осіб тощо. Кожній функції юридичної відповідальності або їх комбінаціям властива певна індивідуальна мета, зумовлена потребами військових та правоохоронних органів і суспільства в цілому.

Тому загальна кінцева мета юридичної відповідальності як цілісного правового інституту досягається за умови реалізації індивідуальної мети кожної функції юридичної відповідальності.

Сучасні вчені виділяють різні види функцій юридичної відповідальності, урізноманітнюючи їхні назви, однак більшість із них одностайні в тому, що до таких функцій варто віднести: правовідновлювальну (правопоновлювальну), або компенсаційну (захисну); превентивну, або виховну (попереджувальну); каральну, або штрафну; інформувальну, або сигналізаційну $[9$, с. $260 ; 10$, с. 226$]$.

Окремі науковці, такі як В. Корельський, В. Перевалова, А. Шабуров, С. Бобровник та інші, пропонують також регулятивну (організуючу) функцію юридичної відповідальності, наголошуючи, що іiі сутність полягає в забезпеченні регулювання суспільних відносин завдяки превенції правопорушень, покарання винних осіб, що їх скоїли, та відновлення порушених прав та інтересів суб'єктів [11, с. 419]. Однак, на нашу думку, у щойно викладеному змісті цієї функції проглядаються риси майже всіх перерахованих вище функцій.

А. Осауленко та інші вчені подають компенсаційну та каральну функції юридичної відповідальності як різновиди правоохоронної функції, яка, на їхню думку, є родовим поняттям щодо щойно названих двох функцій. Така позиція зазначених науковців викликає сумніви, оскільки всі функції юридичної відповідальності якоюсь мірою є правоохоронними [12, с. 200].

Деякі вчені (С.Д. Гусарєв, А.Ю. Олійник, О.Л. Слюсаренко та інші) пропонують як самостійну функцію юридичної відповідальності сигналізаційну, сутність якої, на їхню думку, полягає у спрямованому інформуванні суб'єктів правовідносин про негативні моделі протиправної поведінки 3 метою виховання в особи правових вчинків [13, с. 171]. Однак уже в самому поясненні такого змісту закладено ототожнення пропонованої функції з виховною функцією юридичної відповідальності, адже без інформування про позитивні та негативні сторони життя суспільства й особи неможливий якісний процес виховання.

У зарубіжних наукових джерелах також неоднозначно трактуються функції юридичної відповідальності, їх сутність і соціальна цінність.

Так, польський дослідник А. Шпунтар, критикуючи виховну функцію юридичної відповідальності, наполягає на іiі застарілості й малоефективності висуваючи на перше місце превентивну функцію [14, с. 17-26]. Аналогічної точки зору дотримується й інший його співвітчизник $Є$. Кондек, 
який наголошує на первинності превентивної функції та звуженні впливу й ролі каральної функції юридичної відповідальності суб'єктів правопорушень $[15$, с. $36-45]$.

У своїй інтерпретації подає види функцій юридичної відповідальності працівників органів внутрішніх справ харківський вчений М.В. Калашник, наголошуючи на стимулювальній функції, ліквідаційній (що ліквідує аномалії протиправної поведінки) і формувальній (що формує в працівників органів внутрішніх справ почуття відповідальності за доручену справу шляхом впливу на психологію, свідомість і вольові якості конкретного працівника) [16, с. 71].

Наведені та інші приклади, викладені в багатьох наукових джерелах, свідчать про відсутність єдності поглядів на різноманітні характеристики та проблеми, пов'язані з функціями юридичної відповідальності як у вітчизняній, так і в зарубіжній науковій думці.

Проблематичною $є$ ситуація $з$ висвітленням особливостей їх прояву в спеціальних сферах правоохоронної діяльності нашої держави, якою є сфера охорони та захисту державного кордону України. Тому зупинимось більш детально на цьому.

Насамперед пропонуємо доповнити розроблений наукою та викладений нами в цьому дослідженні перелік функцій юридичної відповідальності новою функцією - контролюючою, яка поряд з іншими найповніше проявляє себе у військовому середовищі. Сутність ії полягає у фіксації всіх фактів будь-яких правопорушень (дисциплінарних, адміністративних тощо) кожного військовослужбовця в службових картках, спеціальних журналах чи на електронних носіях з метою не тільки ведення їх обліку, а й планування системи заходів виховного та превентивного впливу щодо конкретної особи. Контролююча функція юридичної відповідальності сприятиме й правильній кваліфікації подальших правопорушень з боку військовослужбовця, вирішенню питання про доцільність укладення з ним нового контракту про проходження військової служби тощо.

Мають свої особливості прояву та реалізації й деякі інші функції юридичної відповідальності. Так, каральна функція щодо військовослужбовця сфери охорони та захисту державного кордону може проявлятися в застосуванні до нього комбінованої (кумулятивної) відповідальності, наприклад, притягнення військовослужбовця Держприкордонслужби України до кримінальної відповідальності та одночасне його звільнення з військової служби з розірванням контракту [17; 18, ст. 284]. Специфічною ознакою $€$ й те, що на винного військовослужбовця може бути накладено додаткове дисциплінарне покарання згідно з чинним законодавством (наприклад, позачерговий наряд на службу) [19, ст. 48-49]. Слід також зазначити, що в разі притягнення військовослужбовця до кримінальної відповідальності у визначених законодавством випадках до нього можуть бути застосовані такі обмеження: неприсвоєння чергового військового звання, обмеження щодо підвищення у військовому званні або призначення на вищу посаду та ін. [18, ст. 76,150$]$. 
Особливістю превентивної функції юридичної відповідальності військовослужбовців досліджуваної сфери $є$ те, що, ураховуючи колективний комплексний характер їх служби та функціонування військових підрозділів (Держприкордонслужби, Збройних Сил, органів внутрішніх справ тощо) з охорони та захисту державного кордону, зумовлених складністю виконуваних завдань, загальна превенція їхньої протиправної діяльності спрямована не проти будь-яких абстрактних військовослужбовців, а насамперед на військовослужбовців конкретного підрозділу, представник якого допустив правопорушення.

Наслідком реалізації загальнопревентивної функції може бути навіть розформування підрозділу, що вже траплялося в зоні проведення антитерористичної операції на сході України.

Загальнопревентивна функція юридичної відповідальності військовослужбовців сфери охорони та захисту державного кордону також має яскраво виражений колективний характер спрямованості, оскільки ії метою $€$ насамперед формування та вдосконалення сприятливого законослухняного середовища у військовому підрозділі й утвердження належної військової дисципліни, а відповідно, і правомірної поведінки серед його персоналу.

Специфікою $є$ й те, що ненавмисні правопорушення військовослужбовців у сфері охорони та захисту державного кордону України можуть тягнути за собою такі наслідки, які можна розцінювати не як юридичну відповідальність, а як захід для усунення шкоди коштами або позитивними діями самого військовослужбовця (ремонт ненавмисно пошкодженого обладнання, пристроїв тощо) [20, с. 56].

Така діяльність здійснюється за наказом і під контролем безпосередніх начальників. Тут йдеться про незначну матеріальну шкоду, тому службове розслідування скоєного проступку не проводиться за умови, що військовослужбовець вчинив його ненавмисно в умовах очевидності, визнає свою вину i, як правило, виявляє бажання усунути заподіяну шкоду. Відповідно, якщо відсутня юридична відповідальність, то відсутній і прояв ії виховної, превентивної або іншої функції.

Таким чином, узагальнюючи викладене, можна сформулювати таке визначення функцій юридичної відповідальності у сфері охорони та захисту державного кордону України: це основні напрями ії юридичного впливу на особу військовослужбовця, винного у вчиненні правопорушення, та на інший персонал державних органів, на яких згідно із законом покладено обов'язки охорони та захисту державного кордону України, з метою утвердження правомірної поведінки, законності, захисту правопорядку та превенції можливих правопорушень з їхнього боку.

Висновки та перспективи подальших досліджень. Завершуючи дослідження, на підставі викладеного можна дійти таких висновків:

1) функції юридичної відповідальності віддзеркалюють їі соціальну роль, призначення, сутність та зміст як самостійного правового інституту;

2) нестача належних глибоких досліджень функцій юридичної відповідальності породжує різні підходи та розбіжності щодо висвітлення їхніх 
змісту, сутності, видів тощо, що, у свою чергу, висуває потребу їх подальшого поглибленого вивчення;

3) аналіз наявних наукових здобутків, що стосуються нашого предмета дослідження, дав змогу виявити окремі особливості прояву та реалізації функцій юридичної відповідальності військовослужбовців у сфері охорони та захисту державного кордону України.

Викладене вище та запропоновані висновки сприятимуть подальшому поглибленому аналізу функцій юридичної відповідальності та їі проявів у спеціальних правоохоронних сферах, у тому числі й у сфері охорони та захисту державного кордону України, а також ефективному розвитку та якісному прикладному використанню основних положень теорії юридичної відповідальності в галузевих дослідженнях правоохоронної діяльності.

\section{Література}

1. Горшенев В.В. Способы и организационные формы правового регулирования в социалистическом обществе / В.М. Горшенев. - М. : Юрид. лит., 1972. - 256 с

2. Тархов В.А. Гражданское право. Общая часть / В.А. Тархов. - Уфа : Уфимский юрид. ин-т МВД, 1998. - 330 с.

3. Загальна теорія держави і права : [підруч. для студ. юрид. вищ. навч. закл.] / [М.В. Цвік, О.В. Петришин, Л.В. Авраменко та ін.] ; за ред. д-ра юрид. наук, проф., акад. НАПрН України М.В. Цвіка, д-ра юрид. наук, проф., акад. НАПрН України О.В. Петришина. - Х. : Право, 2009. -584 с

4. Теорія держави і права : [підручник] / кол. авт. ; кер. авт. кол. канд. юрид. наук, проф. Ю.А. Ведєрніков. - К. : Ун-т сучасних знань ; Дніпропетровськ : Дніпроп. держ. ун-т внутр. Справ; Ліра ЛТД, 2014. - 468 с.

5. Інститут юридичної відповідальності у демократичних правових системах : [монографія] / [кол. авторів ; за заг. ред. Н. М. Оніщенко]. - К. : Видавництво «Юридична думка», 2009. 216 c.

6. Липинский Д.А. Проблемы юридической ответственности / Д.А. Липинский ; под ред. Р.Л. Хачатурова. - 2-е изд., перераб. и доп. - СПб. : Юрид. центр «Пресс», 2004. - 409 с.

7. Зелена О.В. Проблеми визначення функцій юридичної відповідальності / О.В. Зелена / / Науковий вісник НАВСУ. - 2003. - № 2. - С. 90-96.

8. Трофимова М.П. Функции юридической ответственности : автореф. дис. ... канд. юрид. наук : спец. 12.00.01 «Теория права и государства; история права и государства; история политических и правовых учений» / М.П. Трофимова. - Саратов, 2000. - 26 с.

9. Теорія держави і права : [підруч. для студ. юрид. вищ. навч. закл.] / [О.В. Петришин, С.П. Погребняк, В.С. Смородинський та ін.] ; за ред. О.В. Петришина. - Х. : Право, 2014. - 368 с.

10. Теорія держави і права : [навч. посіб. для підгот. фахівців з інформ. Безпеки] / [О.О. Тихомиров, М.М. Мікуліна, Ю.А. Іванов та ін.] ; за заг. ред. Л. М. Стрельбицької. - К. : Кондор-Видавництво, 2016. - 332 с.

11. Теория государства и права : [учебник для юрид. вузов] / под ред.. В.М. Карельского и В.Д. Перевалова - М. : Издательская группа «Норма - ИНФРА». - M, 1998. - С. 419.

12. Актуальні проблеми теорії держави та права : [навч. пос.] / [Є.В. Білозьоров, Є.О. Гіда, А.М. Завальний та ін.]; за заг. ред. Є.О. Гіди. - К. : ФОП О.С. Ліпкан, 2010. - 260 с.

13. Гусарєв С.Д. Теорія права і держави : [навчальний посібник] / С. Д. Гусарєв, А.Ю. Олійник, О.Л. Слюсаренко. - К. : Всеукр. асоц. видавців «Правова єдність», 2008. - 270 с. 14. Szpunar A. Uwagi o funkciach odnowiedzialnosci odszkodowawczej / A. Szpunar // Panstwo i Prawo. - 2003. - № 1. - S. 17-26.

15. Kondek J.M. Teoretucznoprawne podstawy odpowiedzialnosci odszkodowawczej panstwa za szkody wyrzadzone dziataniem wkadzy publicznei / J.M. Kondek / / Przeglad Sadowy. - 2007. № 1 - S. 36-45.

16. Калашник М.В. Юридична відповідальність працівників органів внутрішніх справ / М.В. Калашник / / Право і безпека. 2012. - № 1 (43). - С. 67-72. 
Б. П. Ганьба, О. Б. Ганъба. Функції юридичної відповідальності й особливості їх прояву... 53

17. Мота А.Ф. Адміністративна відповідальність військовослужбовців за законодавством України : [монографія] / А.Ф. Мота. - Хмельницький : Вид-во Нац. акад. Держ. прикордонної служби України ім. Богдана Хмельницького. - Хмельницький, 2005. - 151 с.

18. Про Положення про проходження громадянами України військової служби в Державній прикордонній службі України : Указ Президента України від 29 грудня 2009 р. № 1115/2009.

19. Про Дисциплінарний статут Збройних Сил України : Закон України від 24 березня 1999 р. // Відомості Верховної Ради. - 1999. - № 22-23. - Ст. 197.

20. Аземша І.Б. Юридична відповідальність: сучасні погляди дискусії та концепції / І.Б. Аземша / / Часопис Київського університету права. - К. - 2010. - № 2. - С. 54-57.

\section{Ано о т ці я}

Ганьба Б. П., Ганьба О. Б. Функції юридичної відповідальності й особливості їх прояву у сфері охорони та захисту державного кордону України. - Стаття.

У статті досліджуються проблеми, що стосуються поняття, сутності, змісту та видів функцій юридичної відповідальності, особливостей їх прояву та реалізації у сфері охорони та захисту державного кордону України.

Ключові слова: функції юридичної відповідальності, юридична відповідальність, військовослужбовець, сфера охорони та захисту державного кордону України.

\section{Анн о т а ци я}

Ганьба Б. П., Ганьба О. Б. Функции юридической ответственности и особенности их проявления в сфере охраны и защиты государственной границы Украины. - Статья.

В статье исследуются проблемы, которые касаются понятия, сущности, содержания и видов функций юридической ответственности, особенностей их проявления и реализации в сфере охраны и защиты государственной границы Украины.

Ключевые слова: функции юридической ответственности, юридическая ответственность, военнослужащий, сфера охраны и защиты государственной границы Украины.

\section{S u m m a r y}

Ganba B. P., Ganba O. B. Functions of legal responsibility, and features of their manifestation in the sphere of protection of the state border of Ukraine. - Article.

The article investigates the issues that relate to the concepts, essence, content and types, functions of legal responsibility, features of their manifestation and realization in the sphere of protection of the state border of Ukraine.

Key words: functions of legal responsibility, legal responsibility, serviceman, sphere of protection of the state border of Ukraine. 